\title{
The Concept and Measurement of Creating Excess Value in Listed Companies
}

\author{
Jaroslaw Kaczmarek
}

\author{
Cracow University of Economics \\ Rakowicka st. 27, 31-510, Cracow, Poland \\ E-mail.kaczmarj@uek.krakow.pl
}

cross $^{\text {ref }}$ http://dx.doi.org/10.5755/j01.ee.29.4.13207

\begin{abstract}
The basic topic of considerations in this paper is an assessment of the creation of value for owners - in an expected and sufficient manner. It indicates that the adopted approach is based on the concept of Expectations Based Management (EBM). The author discusses in this paper the manner of developing measures for the needs of the EBM concept and assessing their usefulness in the conditions of the capital market in Poland. In particular, the aim of this paper is to assess the creation of value for owners of listed companies - in the expected and sufficient manner. From the theoretic and methodical perspective the sub-goal is to expand the field of perception of the market value added measure by introducing the concept of the excess value. At the utility perspective the sub-goal is to verify the effectiveness of excess market added value in the evaluation process of the created value to equity (value for shareholders, owners).

The analysis comprises 20 listed companies (the sectors: energy, chemical industry, fuel and raw materials), whose shares are listed on the Warsaw Stock Exchange. These are the main creators and destroyers of value added. The test period covered the years 2008-2013.

The article proves three research hypotheses, and the general conclusion is that excess market value added provides a more reliable description of capital market changes (companies market capitalisation) as classic market value added, taking into account owners (shareholders) expectations.
\end{abstract}

Keywords: Corporate Value; Creation of Value; Excess Value; Economic and Market Value Added; Value Based Management.

\section{Introduction*}

An effective and efficient company has the ability to arouse the spirit of entrepreneurship and innovativeness development drivers (Drucker, 1986). The effects of corporate development are reflected in the degree of meeting stakeholder expectations. Corporate value and its creation are the basic financial effects. Shareholder value corresponds to corporate value reduced by external capital (Matuleviciene $\&$ Stravinskiene, 2015). Therefore, increased shareholder value is conditioned by an increase in corporate value (increased value for all stakeholders) (Rappaport, 2006).

Sustained efforts aimed to maximise corporate value are major management determinants (Koller, Goedhart \& Wessels, 2010). In the area of measurement there is a shift from tools based on accounting and financial methods to those determined by market factors, directly reflecting corporate value creation methods (Parker, 1968). They allow for eliminating the deficiencies attributed to accounting and financial measures, and they measure value creation with consideration given to capital acquisition costs (Myers 1984).

The VBM concept (Value Based Management) subordinates management functions to maximising corporate value. Presently, this concept is an accepted standard for measuring and assessing company performance (Srivastava, et al., 1998; Black \& Wright, 2001).

The measurement of corporate effectiveness in terms of created value is based on valuation (estimation of a company's value) (Cornell \& Shapiro, 1987) aimed to determine the quantified assessment of value changes in the course of time and, at a later stage, to motivate company executives to implement strategies for maximising corporate value.

The VBM concept is becoming increasingly popular in Poland. However, due to a small number of businesses which apply it in practice, it is still too early to cite clear-cut opinions on its usefulness. Undoubtedly, management styles and targets have undergone major changes. A company's financial result is no longer regarded as the basic criterion for assessing its effectiveness - the short-term maximisation of the net financial result is not as yet equivalent to a steady increase in corporate value in long-term periods (Dean, 1954).

The VBM concept traditionally relies on such value creation measures as Economic Value Added $\left(\mathrm{EVA}^{\mathrm{TM}}\right)$ and Market Value Added (MVA). These are classical and useful measures, but they have some deficiencies. The key drawback is the fact that they do not give consideration to the expectations of owners, i.e. stockholders. The inclusion of their interests requires a shift in the corporate management process from VBM to Expectations Based Management (EBM) (Copeland, Dolgoff \& Moel, 2004). As in the case of any management concept, the major issue is effectiveness measures. In this particular case, they relate to the proposal for new measures - "new" in the sense of incorporating stockholders' expectations into value creation calculation.

The author discusses in this paper the manner of developing such measures and assessing their usefulness in the

\footnotetext{
* Publication financed by funds granted to the Management Faculty of Cracow University of Economics under the scheme for subsidising university research potential.
} 
conditions of the capital market in Poland. In particular, the aim of this paper is to assess the creation of value for owners of listed companies - in the expected and sufficient manner. From the theoretic and methodical perspective the sub-goal is to expand the field of perception of the market value added measure by introducing the concept of the excess value. At the utility perspective the sub goal is to verify the effectiveness of excess market added value in the evaluation process of the created value to equity (value for shareholders, owners).

The study examines 20 listed companies (the sectors: energy, chemical industry, fuel and raw materials), whose shares are listed on the Warsaw Stock Exchange. These are the main creators and destroyers of value added, primarily constituting the main stock index (WIG-20). The test period covered the years 2008-2013.

The article puts forward three research hypotheses which refer to the mid-term period of the analysed changes:

H 1. a strong and statistically significant correlation between changes in excess market value added and changes in companies' market capitalisation,

H 2. excess market value added is a more effective tool than market value added in describing capital market changes, assessed by changes in companies' market capitalisation,

H 3. despite the fact that market value added combines engaged capital with total economic value added, the measure of economic value added (internal valuation) is not consistent with external valuation - market value.

\section{The Measurement of Created Value}

\section{The Current Status}

The key component of VBM processes is the measurement of corporate effectiveness from the perspective of created value. The major measures include $\mathrm{EVA}^{\mathrm{TM}}$ and MVA.

The EVA ${ }^{\mathrm{TM}}$ concept describes surplus value either as the difference between NOPAT ${ }^{\mathrm{C}}$ (corrected Net Operating Profit After Taxes) and charges for invested capital along with equivalents $\mathrm{IC}^{\mathrm{EC}}$ (Stern et al. 1996), or as the difference between WACIC ${ }^{\mathrm{C}}$ (Weighted Average Cost of Invested Capital with equivalents) and the $\mathrm{ROIC}^{\mathrm{C}}$ rate of return on invested capital (Hartman, 2000). The cost of equity is determined with the use of CAPM (Capital Asset Pricing Model) (Benninga \& Sarig, 2003; Bilgin \& Basti, 2014). Operating result corrections relate to the adoption of the concept measurement of creating value for owners (financing based exclusively on equity) and consideration given to changes to equivalents in a given period as well as the elimination of the components of the operating results which are not based on operating assets (net assets) (Peasnell, 1982; O’Hanlon \& Peasnell, 2000).

The MVA theoretical concept is described by the difference between a company's market value and the value of invested capital (Hillman \& Keim, 2001). It comprises both equity and external capital, increased by equivalents. A positive value of MVA confirms the existence of a premium added on the market to invested capital. The opposite situation is referred to as MVL - Market Value Lost. The added premium is a benefit for all financing parties - the suppliers of invested capital (Modigliani \& Miller, 1958).

\section{Critical Remarks}

As an absolute value, EVA can hardly be subject to comparative analysis, but when referred to the value of invested capital, it facilitates determining relative measure. The adopted approach can be used for the needs of timebased comparative analyses and in relation to the benchmark (the group of reference) (Djuric et al., 2013). With regard to economic value added, critical comments also refer to the objective of the performed measurement - it is an internal measure of created value, and the results of analyses are not subject to market objectivisation.

Market assessments which make use of the external measure of created value can be based on the MVA concept. It does not describe company performance but the opinions about it.

Thus, it should be noted that the possibility of determining values exists only at company level, not at business entity level (Nyiramahoro \& Shooshina, 2001). Moreover, MVA offers benefits for owners only in the form of market capitalisation (without CDS - Cash Distributions to Shareholders), and market capitalisation - together with equivalents - is opposed to the book value of invested equity (Miller \& Scholes 1978). The main critical remark is that MVA is an absolute measure, which makes a comparative analysis hardly possible.

\section{Modifications For the Purpose of Research}

Because operating result corrections in the $\mathrm{EVA}^{\mathrm{TM}}$ concept assume financing exclusively based on equity, for the purpose of research conducted in the paper (creation of shareholder value), and in order to determine economic value added for owners $\left(\mathrm{EVA}_{\mathrm{E}}\right)$, WACIC ${ }^{\mathrm{C}}$ was replaced by $\mathrm{ECC}^{\mathrm{C}}$, calculated for equity with equivalents $\mathrm{IC}^{\mathrm{C}} \mathrm{E}$.

$$
E V A_{E}=\left(\frac{N O P A T_{t}^{C}}{I C_{E t-1}^{C}}-E C C_{t}^{C}\right) \cdot I C_{E t-1}^{C}
$$

From the perspective of company owners (shareholders), the external assessment of effectiveness expressed by MVA (Market Value Added to Equity) is the difference between market capitalisation $\mathrm{MV}_{\mathrm{E}}$ and the value of invested equity $\mathrm{IC}_{\mathrm{E}}^{\mathrm{C}}$ (together with equivalents). It assumes positive values when ROIC ${ }_{\mathrm{E}}^{\mathrm{C}}$ (Return on Invested Equity Capital) exceeds its cost $\mathrm{ECC}^{\mathrm{C}}$ (Equity Capital Cost).

From the point of view of the research analysis presented in the paper it was assumed that a company's market value $\left(M V_{E}\right)$ reflects the present value of engaged equity $\left(\mathrm{IC}_{\mathrm{E}}\right)$ and the resulting future economic surplus $\left(\sum \mathrm{EVA}_{\mathrm{Et}}\right)$. The remarks concerning the scope of corrections and equivalents remain valid.

$$
\begin{aligned}
& M V A_{E}=M V_{E}-I C_{E}^{C} \\
& M V A_{E}=\sum_{t=1}^{\infty} \frac{E V A_{E t}}{\left(1+E C C_{t}^{C}\right)^{t}} \quad M V_{E}=I C_{E t-1}^{C}+\sum_{t=1}^{\infty} \frac{E V A_{E t}}{\left(1+E C C_{t}^{C}\right)^{t}}
\end{aligned}
$$

The extended form of $\mathrm{MV}_{\mathrm{E}}$ comprises two components economic value for the period of forecast and residual economic value (Pfeiffer 2004), as in Gordon's model, with the fixed rate of changes $(q)$ to economic value after the period of forecast. 


\section{Shareholder Expectations vs Value Creation}

The measures of economic and market value added (within the framework of the VBM concept) have a major deficiency - they do not give consideration to owners' (shareholders') expectations. The positive values of these measures $d o$ indicate an increase in corporate value, but they do not justify the view that they also increase shareholder value (Rappaport, 2006).

This situation has major implications for shareholders and the capital market. Return on investment below shareholders' expectations - despite corporate value creation - leads to a decrease in share prices. The reverse situation results in increased share prices - see Table 1 .

The reason for the above is a considerable difference in understanding the concepts of corporate value and shareholder value creation. The latter process requires the generation of actual economic gains $\left(\mathrm{ROIC}_{\mathrm{R}}^{\mathrm{C}}>\mathrm{WACIC}_{\mathrm{R}}\right.$ ) as well as the realization of the resulting value through, among others, increased share prices, which is determined by better results than those expected by investors ( ROIC $^{C}{ }_{R}$

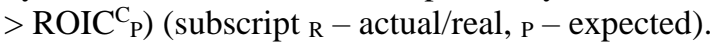

Table 1

\section{The Matrix of the Factors of Economic Value Added and} Share Prices

\begin{tabular}{|c|c|c|}
\hline & ROIC $_{R}{ }_{R}<$ WACIC $_{R}{ }_{R}$ & ROIC $_{R}{ }_{R}>$ WACIC $_{R}{ }_{R}$ \\
\hline $\operatorname{ROIC}^{C}{ }_{R}>\operatorname{ROIC}_{P}{ }_{P}$ & $\begin{array}{c}- \text { EVA } \\
+ \text { share price } \\
\end{array}$ & $\begin{array}{c}+ \text { EVA } \\
+ \text { share price }\end{array}$ \\
\hline \multirow[t]{2}{*}{ ROIC $^{C}{ }_{\mathrm{R}}<$ ROIC $^{\mathrm{C}}{ }_{\mathrm{P}}$} & $\begin{array}{c}- \text { EVA } \\
- \text { share price }\end{array}$ & $\begin{array}{c}\text { + EVA } \\
\text { - share price }\end{array}$ \\
\hline & Do not invest & Invest \\
\hline
\end{tabular}

Source: (Copeland, Dolgoff \& Moel, 2004).

Therefore, it can be concluded that the classical construction of economic value added can only provide information on the potential of creating shareholder value. The criticism of this measure leads to its modified version in which the key criterion for assessing shareholder value creation is neither absolute value nor its change but a comparison between actual (real) value and expected value, predicted by the market (shareholders), included in market share prices (the value of future growth). In order to meet this requirement it is necessary to apply the concept of excess value (a shift towards EBM). This change leads to a positive assessment. This approach, however, has its drawbacks - this criterion is much more restrictive than classical value added (the above remarks also refer to market value added).

\section{An Analysis of Excess Return and Excess Value}

An analysis of professional literatures - in the context of the objectives of this paper - focuses on two areas of research: excess return and value added.

The concept of return on shares (Fernandez, 2001), currently referred to as Total Shareholder Return (TSR), allowed A. Rappaport to develop the concept of Excess Return (excess TSR - Total Shareholder Return) (Rappaport 1999) (also alfa ratio) (Jensen 1968), presented in a broader context as CAR - Cumulative Abnormal Return (Capron \& Pistre 2002).
To sum up, excess return on the capital market indicates the investment returns which exceed a benchmark or an index in the conditions of similar risk. In a formal approach, excess return is the rate of return that exceeds what was expected or predicted by models like CAPM (capital asset pricing model). Excess return was incorporated into this model by M. Grinblatt and S. Titman (Grinblatt \& Titman, 1989).

This understanding of excess return is controversial. Rather, it is generated by the skill of the investor or portfolio manager, and is one of the most widely used measures of risk - adjusted performance.

The concept of residual income was developed earlier on the basis of an intuition based approach proposed by the first microeconomists (A. Marshall, G. Preinreich). It was used for the first time by D. Solomons, and it became widely used in management accounting and business economics (Solomons, 1965). However, the key role was played by the works of K. Peasnell and J. Ohlson (Peasnell, 1982; Ohlson, 1995), as well as by Stewart's proposal to use economic value added $\left(\mathrm{EVA}^{\mathrm{TM}}\right)$ in corporate finance. In the recent years, a new definition of residual income (Systemic Value Added) was proposed by C. Magni (Magni, 2003).

The two areas of research are combined in Expectations Based Management (Copeland, Dolgoff \& Moel, 2004). This concept treats excess residual income as the difference between actual and expected economic return. J. O'Hanlon and K. Peasnell present a multiannual approach to excess return from the perspective of shareholder value creation (O’Hanlon \& Peasnell, 2002).

In the recent years, research on excess return has been conducted on stock exchanges (Perotti \& Wagenhofer, 2011; Baker, Brendan \& Wurgler 2011) and bond markets (Bosse, Brian \& Philips, 2013) in the USA, in emerging markets (Gilmore \& Hayashi 2011), and the Far East market (Nurwati \& Ramdi, 2013). Also, stock exchange organizations and banks (e.g. Euronext, and ECB) assess this measure for the needs of capital market assets. The above research studies, however, do not refer to excess value only from the perspective of the use of equity. Nevertheless, they confirm the usefulness of excess return measures in the conditions of the analysed markets.

\section{The Proposed Concept of Shareholder Excess Market Value Added}

The measurement of shareholder value is clearly and intuitively described by TSR (Fernandez, 2001). In analysing its significance for shareholder value creation, a reference can be made to measures based on creating value added (Kaczmarek, 2014; The Quantification...).

TSR is a relative assessment of the multiplication of values, but it requires relativisation - it should be referred to other known (benchmark) or expected rates of value creation (return required by owners). According to excess TSR idea, shareholder value is created when real total return exceeds the expected level (expressed by the cost of equity). However, the question arises whether a positive value of excess TSR is a basis for final assessments, and whether, importantly, shareholder value creation meets owners' expectations (Day \& Fahey, 1988). Hence an isolated approach is replaced by referring and relativising a 
company's TSR to a reference group's TSR (benchmark) (McTaggart et al., 1995). Its positive value indicates the achievement of SSR (Superior Shareholder Return) (Alberts \& McTaggart, 1984). However, there are valid arguments in favour of the opinion that shareholder value is also created in the case of positive excess TSR, even if it does not represent superior return (Nyiramahoro \& Shooshina, 2001).

An attempt to seek direct analogies between the relativisation of $\mathrm{MVA}_{\mathrm{E}}$ and TSR is not justified - by its nature, TSR is a relative measure. From the point of view of assessing value creation it is justified to determine changes to $\mathrm{MVA}_{\mathrm{E}}$ in the course of time (in the subsequent periods), which would describe an increase in value creation (McIntyre 1999). As an absolute value it can hardly be used in comparative analyses, but when referred to invested equity, it can result in determining a relative value of MVA.

An interesting proposal made in this study (the results are presented in this paper) is the inclusion of the expected increases in market value $\mathrm{MV}_{\mathrm{E}}$ (company capitalisation). It provides a basis for determining expected $M_{E P}$ and excess $\mathrm{MVA}_{\mathrm{EN}}$ in relation to real MVAER. This assessment, then, relativises the cost of equity $\mathrm{ECC}_{\mathrm{E}}^{\mathrm{C}}$, which reflects the minimal expected rate of return (an increase in $\mathrm{MV}_{\mathrm{E}}$ ) (Mikołajek-Gocejna 2010).

$$
\begin{aligned}
& M V A_{E P}=M V_{E t-1} \cdot\left(1+E C C_{t}^{C}\right)-I C_{E t-1}^{C} \\
& M V A_{E N}=M V A_{E R}-M V A_{E P}
\end{aligned}
$$

The determination of excess EVA $\mathrm{EN}_{\mathrm{EN}}$, with consideration given to the minimal rate of return, is not justified $-\mathrm{EVA}_{\mathrm{E}}$ comprises the criterion which corresponds to the marginal profitability threshold. Its positive value indicates that company owners receive (or should receive) higher than expected return on invested equity (determined by its cost). However, it is not verified by the market because EVA $\mathrm{A}_{\mathrm{E}}$ is an internal measure of created value.

For this reason, external assessment measures MVAEN and $\mathrm{MV}_{\mathrm{E}}$ are used in research on mutual correlations between shareholder value creation measures.

\section{Research Methodology and Statistical Procedures}

Three hypotheses formulated in the introduction form a coherent structure (model) connecting substantively examined categories (variables): changes of market value to equity (the company capitalization $-\mathrm{dMV}_{\mathrm{E}}$ ), market value added to equity (dMVA $A_{\mathrm{ER}}$ ), excess market value added to equity (MVAFR)also economic value added to equity ( $\mathrm{RI}_{\mathrm{E} \sim \mathrm{E}} \mathrm{EVA}$ ). This is done at two layers (perspectives) of measurement: external and internal measure of value created.

In terms of external evaluation of value creation, substantively reasonable starting point (the first step) is to study the correlation used to verify the H1 hypothesis. If there is a correlation, it is possible to assess the comparative strength of the two correlations for the verification of the $\mathrm{H} 2$ hypothesis (second step). A different relationship is generically the study of the correlation between the variables at the layer (perspective) of the internal assessment and external value creation, used to verify the hypothesis H3 (step three). In this case, it is contenwise only to study the interdependence between the two heteronymous categories (variables).

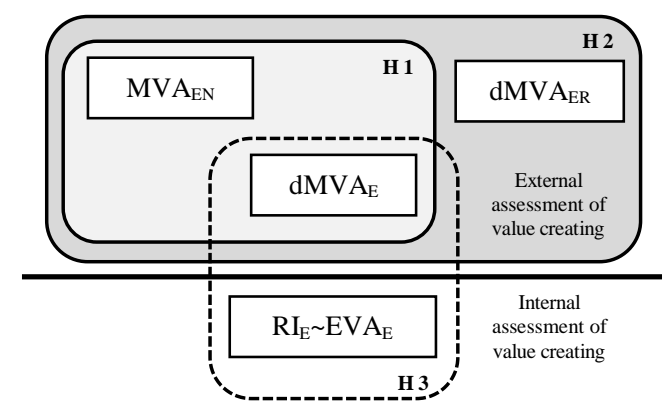

Figure 1. Structure of Assessment of the Analysed Measures of the Created Value.

Source: author's own research

The accumulated research material (empirical data) has been subjected to numerical statistical analysis in the article. In the first stage, I made multifaceted data visualization. I used categorized bar graphs, line graphs for time series, and statistical dispersion diagrams.

In the second stage, using statistical tests, I verified economic hypotheses presented earlier. Economic H1 and H3 hypotheses were examined by the test for a single correlation coefficient. I used the coefficient of $r$-Pearson (r) as a measure. In order to examine the economic $\mathrm{H} 2$ hypothesis I needed to reach for the custom tools of mathematical statistics. It was examined by a test for equality of two related correlation coefficients. The problem of this method is subject to, among others, studies (Meng 1992; Steiger 1980). I used William's test statistic $\left(\mathrm{T}_{2}\right)$ :

$$
T_{2}=\left(r_{j k}-r_{j h}\right) \sqrt{\frac{(N-1)\left(1+r_{k h}\right)}{2\left(\frac{N-1}{N-3}\right)|R|+\bar{r}^{2}\left(1-r_{k h}\right)^{3}}}
$$

where:

$$
\begin{aligned}
\bar{r}^{2}= & \frac{1}{2}\left(r_{j k}+r_{j h}\right) ;|R|=\left(1-r_{j k}^{2}-r_{j h}^{2}-r_{k h}^{2}\right)+\left(2 r_{j k} r_{j h} r_{k h}\right) \\
& \mathrm{N}-\text { sample size, } \\
& \mathrm{r}-\text { Pearson correlation coefficient. }
\end{aligned}
$$

While testing I assumed critical significance level $\alpha=0.05$, to which the test $p$-value (asymptotic significance, probability value) is compared. The test $\mathrm{p}$-value below the critical level of significance entitled to act ad hoc as if the null hypothesis of no correlation had been rejected, which is the basis for the adoption of the alternative hypothesis of the existence of correlations. Of course, the use of $\mathrm{p}$-value has been a matter of considerable discussion in statistics ( $p$ value is a parameter for a given observation, sample), but mainly in the area of its misinterpretation (i.a. Wasserstein \& Lazar 2016; Hubbard \& Bayarri 2012).

Analysis was performed in Statistica 12, Excel 2016 and R 3.4 programs.

\section{The Results of the Empirical Research of Excess Value}

The presented theoretical and cognitive considerations are verified by the results of the research study of 104 companies listed on the Warsaw Stock Exchange (with a total of 369 companies). They are major factors of value creation and destruction, and most of them represent stock exchange indices (primary and sectorial). The study covers the period 2008-2013.

The course of the analysis was consistent with the adopted methodological approach, comprising the presented 
methods and tools (beta risk factors in CAPM calculated for companies and sectors of 10 years, i.e. 120 monthly periods). The exception was the use of the surrogate of economic value added (the lack of financial and accounting information) in the form of Hamilton's and Marshall's concept of residual income (RI) - without operating result corrections and equivalents of invested capital.

The companies are analysed from the perspective of value creation and correlations between its measures by sectors: production (energy, chemicals, fuels and raw materials - 20 companies), real estate (developers - 27 companies), construction (39 companies), and the manufacture of building materials (18 companies). The results of an analysis of developers, construction companies and building materials manufacturers are presented in other publications (Kaczmarek, 2014).

The results of research presented in the paper refer to the production sector - 20 listed companies belonging to the following sectors: energy, chemical industry, fuel and raw materials. Most of them (9/20) constitute the primary WIG20 stock index (the remaining 11 companies representing the financial sector) as well as sectorial indices (WIGPALIWA, WIG-CHEMIA, WIG-ENERG, WIGSUROWC).
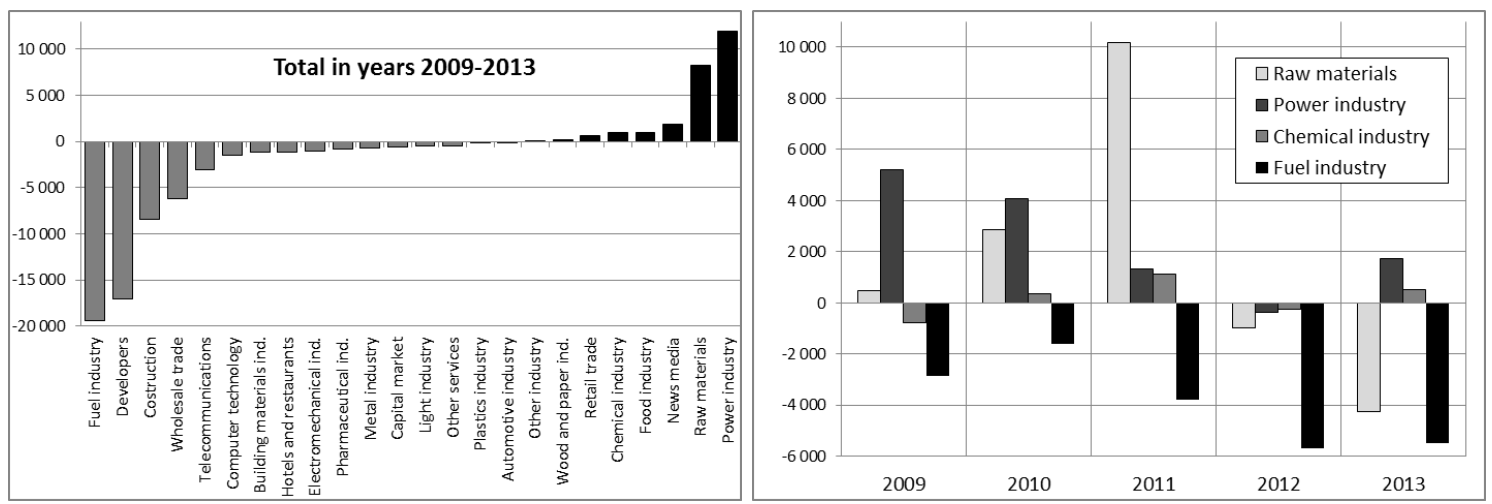

Figure 2. Economic Value Added $\mathrm{RI}_{\mathrm{E}} \sim \mathrm{EV} \mathrm{A}_{\mathrm{E}}$ in the Sectors of Poland's Economy (2009-2013, Listed Companies, in PLN Millions). Source: Author's own Research Based on Information and Figures Provided by Notoria.pl, gpw.pl, vba.pl, and Financial Information Provided by Particular Companies

During the 2008-2013 period (the requirement of data cohesion and the maintenance of the required number of companies limits the scope of research to medium-term periods) the analysed companies accounted for $95 \%$ of positive and $82 \%$ of negative value added generated by all listed companies as part of production activities (industry and energy - a total of 181 companies). A significant role in Poland's economy and a high share in reducing and creating economic value added is the reason for which these problems are given much attention in the further parts of the paper (companies are identified by their so-called ticker - a three-letter abbreviation).

An assessment of the 5-year period of the performance of listed companies (publicly traded and of key significance to the economy) is negative (see Figure 2.). The particular sectors created economic value added in the amount of PLN 25.0bn, while destroying economic value at the level of PLN $61.9 \mathrm{bn}$, thus leading to a negative balance. Value was created mainly in the energy industry and the supply of raw materials, while value losses were recorded in the fuel industry, developer activities, construction, wholesale trade and telecommunication. The four analysed sectors (energy, fuels, chemicals and raw materials) recorded the highest annual $\mathrm{RI}_{\mathrm{E}} \sim \mathrm{EVA}_{\mathrm{E}}$ values as well as diversified changes. In each year, the fuel industry recorded value losses, especially in the period of the last two years. On the other hand, the raw materials industry, following the period of value creation (2009-2011), entered a period of rapid value destruction.

Out of the 20 analysed listed companies, 9 entities represent the WIG-20 index. It recorded rapid decreases in 2009 as a result of the financial crisis and considerable changes to the market value of particular companies.
Obviously, these changes (company capitalisation $-M V_{E}$ ), being a component of the index, are highly correlated to its changes $(r=0.85, \mathrm{p}-$ value $=0.0000 \ldots<\alpha=0.05)$.

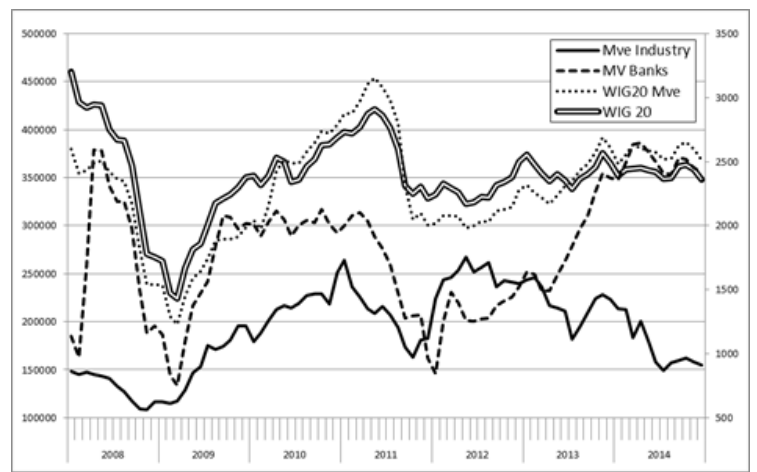

Figure 3. Primary WIG-20 Stock Index and Market Value MVE in Industrial and Banking Sectors (2008-2013, Listed Companies, in Points and PLN Millions). Source: same as Figure 2.

The unfavourable conditions in 2009 were due to a rapid decline in $\mathrm{MV}_{\mathrm{E}}$ in the financial sector - mainly banks and insurance companies - which, apart from the analysed 9 industrial companies - constitute WIG-20, having a major impact on its value. Apart from an increase in $\mathrm{MV}_{\mathrm{E}}$ in industrial companies, WIG-20 recorded a rapid decrease. In the subsequent years it was supported by the stabilisation of industrial and financial companies, while in $2013 \mathrm{MV}_{\mathrm{E}}$ in industrial companies fell, having no adverse impact on WIG-20 as a result of increased $\mathrm{MV}_{\mathrm{E}}$ values in financial companies (see Figure 3.). 


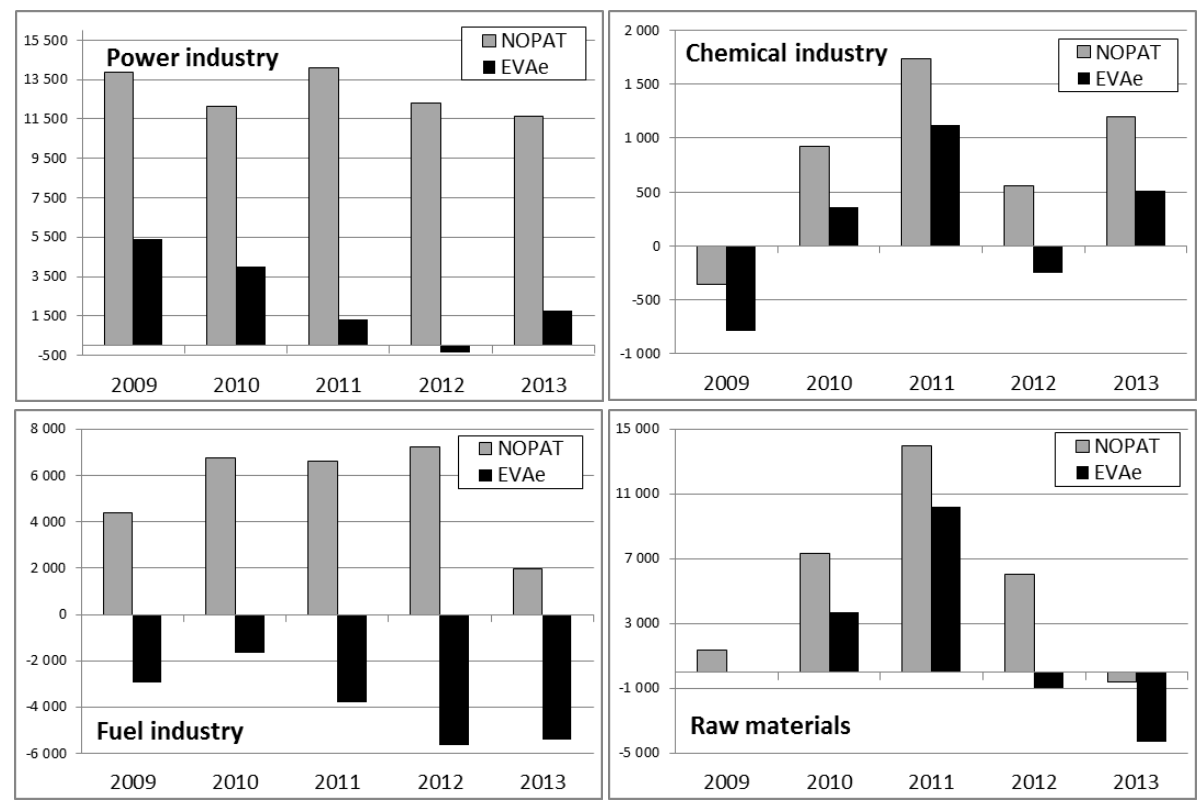

Figure 4. Economic Value Added $\mathrm{RI}_{\mathrm{E}} \sim \mathrm{EV} \mathrm{A}_{\mathrm{E}}$ and Operating Profit NOPAT in the Sectors of Poland's Economy (2009-2013, listed Companies, in PLN Millions). Notes: The Visualization Refers to Chirped (Compressed) Number as an Annual Average Discounted. Source: Same as Figure 2.

Economic value added for owners $\mathrm{EVA}_{\mathrm{E}}$ has various relations to operating profit values. In the energy sector high positive NOPAT values are accompanied by relatively low EVA $_{E}$ values, but positive in the most of the analysed years (weak correlation, $\mathrm{r}=0.2171, \mathrm{p}-$ value $=0.0000 \ldots<\alpha=0.05$ ). The fuels industry, on the other hand, recorded high positive NOPAT values corresponding to high and decreasing

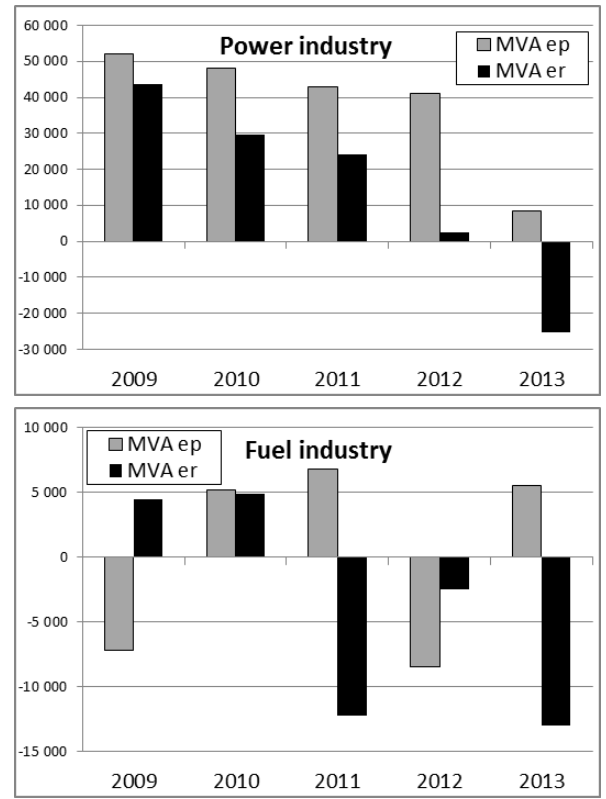

negative $\mathrm{EVA}_{\mathrm{E}}$ values (weak correlation, $\mathrm{r}=0.2404$, $\mathrm{p}-$ value $=0.0000 \ldots<\alpha=0.05$ ). In the chemical and raw materials industries operating profit changes were accompanied by the same trend in EVAE changes (very strong correlation, respectively: $\mathrm{r}=0.9542$ and $\mathrm{r}=0.9251, \mathrm{p}-$ value $=0.0000 \ldots<\alpha=0.05$ ), with its considerable decreases leading to negative $\mathrm{EVA}_{\mathrm{E}}$ values (see Figure 4.).

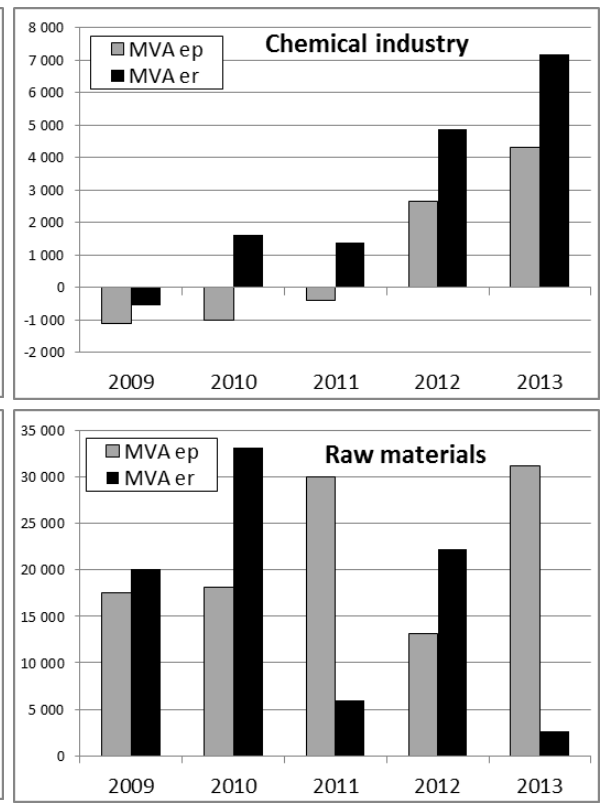

Figure 5. Expected (MVAep) and Real Market Value Added (MVAer) in the Analysed Companies by Sector (in PLN millions). Notes: Same as Figure 4. Source: same as Figure 2.

The difference between the expected MVAEP and the real MVAER is described by the excess MVA $\mathrm{EN}_{\text {(see Figure }}$ 5.). It may be assessed in terms of changes in the market value of $\mathrm{MV}_{\mathrm{E}}$ for given companies. In this manner differences emerge in the assessment of creating the value added of MVAER performed by the market in terms of the value added of expected $M V A_{E P}$ and at the same time in reference to the company market value of $M V_{E}-$ its capitalization. 


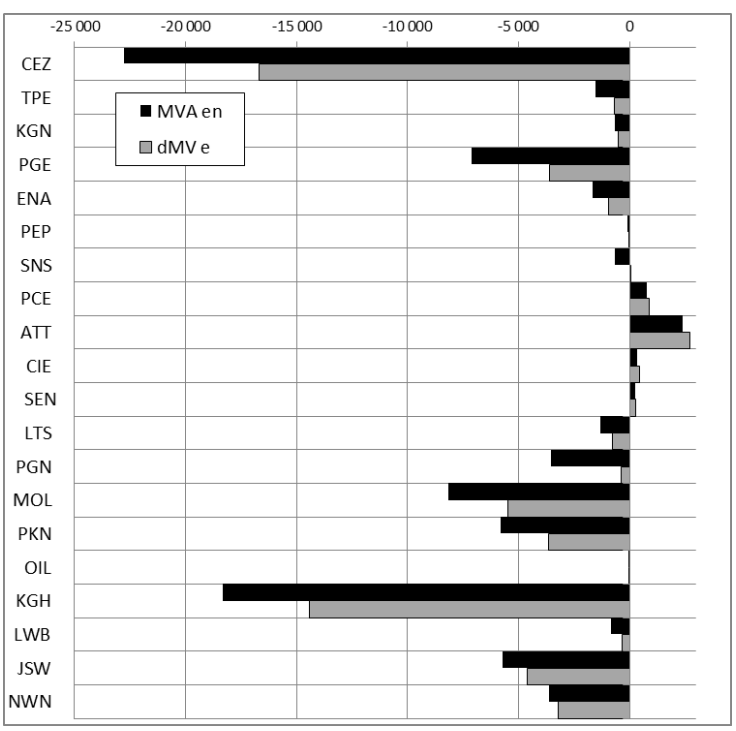

Figure 6. Excess Market Value Added (MVAEN) and changes to Market Value $\left(\mathrm{dMV}_{\mathrm{E}}\right)$ in the Analysed Companies in 2013 (in

PLN Millions). Source: Same as Figure 2.

In the last year of the analysis (2013), in all the 20 companies the value of $\mathrm{MVA}_{\mathrm{EN}}$ (in other words, the market premium in terms of expected minimum return) was lower than changes (increase/decrease) in market value $\mathrm{MV}_{\mathrm{E}}$ (see Figure 6.).

In the set of the negative values of both categories assessments should be negative (e.g. CEZ, KGH, MOL, PGE - a total of 16 companies). In the case of ATT company, MVAEP was negative, while MVAER was positive - the assessment is positive because of the existence of a market premium.

Positive values of both categories (MVA $\mathrm{A}_{\mathrm{EN}}$ and $\mathrm{dMV}$ ) were only recorded by four companies (PCE, ATT, CIE and SEN) - positive assessment.

\section{Verification of Economic Hypotheses}

Giving the analysis of excess market value added to equity $\left(\mathrm{MVA}_{\mathrm{EN}}\right)$ a dynamic dimension, the changes in this category can be assessed in relation to changes in $\mathrm{MV}_{\mathrm{E}}-$ not so much in absolute terms in the individual periods, as their general direction. The result is a very strong correlation, $\mathrm{r}=0.9313, \mathrm{p}-$ value $=0.0000 \ldots<\alpha=0.05$ (see Figure 7.).

This is the first step of the study from the perspective of the external measure of created value. Its effect is to accept as true the following hypothesis:

$\mathrm{H}$ 1.there is a strong and statistically significant correlation

between changes in market excess value added and

changes in companies' market capitalization.

In the second step, I peformed, in the first place, the assessment of the correlation of changes in the $\mathrm{MV}_{\mathrm{E}}$ and $\mathrm{MVA}_{\mathrm{ER}}$. The achieved result is a strong correlation, $\mathrm{r}=0.7027, \mathrm{p}-$ value $=0.0000 \ldots<\alpha=0.05$ (see Figure 7.). Then, to prove the authenticity of the second hypothesis - on the outcome of the assessment of comparative strength of the correlation of two pairs of variables $\left(\mathrm{MVA}_{\mathrm{EN}}-\mathrm{dMV}_{\mathrm{E}}\right.$ and $\mathrm{dMVA}_{\mathrm{ER}}-\mathrm{dMV}_{\mathrm{E})}-\mathrm{I}$ used the test for the equality of the two associated correlation coefficients $\left(\mathrm{T}_{2}\right)$. Its result as a $\mathrm{p}$ value $=0.0000 \ldots<\alpha=0.05$ provides evidence that examined correlations are different. In this case we compared the strength of the two correlations. Correlation $\mathrm{MVA}_{\mathrm{EN}}-\mathrm{dMV}_{\mathrm{E}}$
$(0.9313)$ is stronger than the correlation $d M V A_{E R}-d M V_{E}$ (0.7027). This is the basis of acceptance as true the following hypothesis:

$\mathrm{H}$ 2. excess market value added is a more effective tool than market value added in describing capital market changes, assessed to changes in companies' market capitalization.

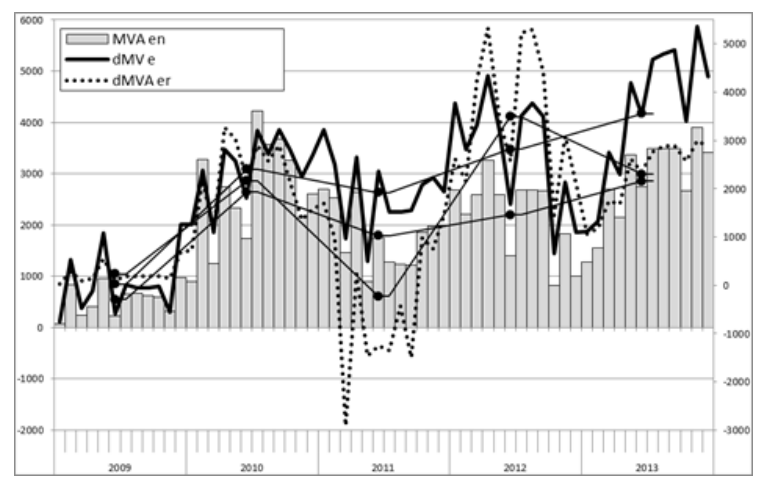

Figure 7. Changes to Market Value $\left(\mathrm{dMV}_{\mathrm{E}}\right)$, Market Value Added (dMVAer) and Excess Value (MVAen), and Economic Value Added (EVAE) in the Analysed Companies (in PLN millions). Notes: Monthly Observations for Superstructure (Superset) of the Studied Companies (Industry Section). Scatter Chart (with Lines Connecting Points) Refers to the Chirped (Compressed) Number as an Annual Average Discounted. Source: Same as Figure 2.

The third step is the study of the correlation between the variables from the perspective of the internal assessment and external value creation. In this case, it is justified only to study the interdependence between the economic value added to equity $\left(\mathrm{RI}_{\mathrm{E}} \sim \mathrm{EV} \mathrm{A}_{\mathrm{E}}\right)$ and changes of market value

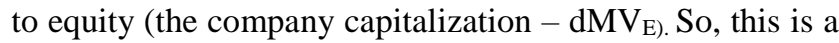
medium correlation, $\mathrm{r}=0.5267, \mathrm{p}-$ value $=0.0000 \ldots<\alpha=0.05$ (see Figure 8). This is also illustrated in the scatter graph, while testing the correlation (linear regression) between the analyzed variables shows low value of the determination coefficient $R^{2}$. Thus, the value of $\mathrm{RI}_{\mathrm{E}} \sim \mathrm{EVA}_{\mathrm{E}}$ only explains $27.74 \%$ of the variability of $\mathrm{dMV}_{\mathrm{E}}$. This is the basis of acceptance as true the following hypothesis:

$H$ 3.despite the fact that market value added combines engaged capital with total economic value added, the measure of economic value added (internal valuation) is not consistent with external valuation - market value.

Obviously, $\mathrm{MV}_{\mathrm{E}}$ is based on the assessment of companies' future potential, which can be inconsistent with the assessment of current results affecting value added $\mathrm{RI}_{\mathrm{E}} \sim \mathrm{EVA}_{\mathrm{E}}$. These results, however, are real - not expected, as in the case of $\mathrm{MV}_{\mathrm{E}}$ - which poses questions to companies' ability to create value added. 


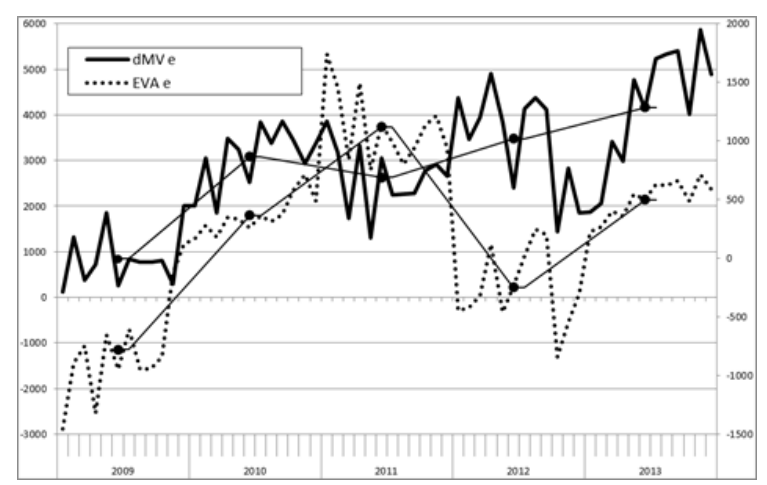

Figure 8. Changes to Market Value $\left(\mathrm{dMV}_{\mathrm{E}}\right)$, Market Value Added (dMVA $\left.A_{E R}\right)$ and Excess Value (MVA $\left.A_{E N}\right)$, and Economic Value Added (EVAE) in the Analysed Companies (in PLN Millions). Notes: Same as Figure 7. Source: same as Figure 2.

The assessment of changes to value added $\mathrm{RI}_{\mathrm{E}} \sim \mathrm{EVA}_{\mathrm{E}}$ and market value $\mathrm{MV}_{\mathrm{E}}$ should be supplemented by the identified decrease in the dispersion of objects (the analysed companies), with a general concentration at the origin of the coordinate system. This means that there is an advantage of relatively small changes to values in the last year of analysis. (see Figure 9.). In a dynamic approach, this movement of objects is described by the trajectory of total values (central point), beginning in quadrant $\mathrm{I}\left(+\mathrm{EVA}_{\mathrm{E}} ;+\mathrm{dMV} \mathrm{V}_{\mathrm{E}}\right)$, with a transfer (2011 and 2012) through quadrant II (+EVAE; $\left.\mathrm{dMV}_{\mathrm{E}}\right)$, and quadrant III $\left(-\mathrm{EVA}_{\mathrm{E}} ;+\mathrm{dMV}_{\mathrm{E}}\right)$, ultimately leading to quadrant IV $\left(-\mathrm{EVA}_{\mathrm{E}} ;-\mathrm{dMV}_{\mathrm{E}}\right)-\mathrm{a}$ basis for a negative assessment.

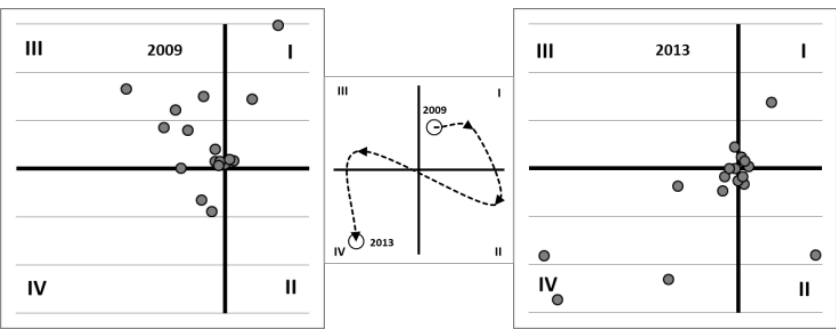

Figure 9. The Dispersion of the Analysed Companies in 2009 and 2013, and the Path of the Central Point in 2009-2013 Economic Value Added $\left(\mathrm{RI}_{\mathrm{E}} \sim \mathrm{EVA} \mathrm{A}_{\mathrm{E}}\right)$, and Changes to Market Value $\left(\mathrm{dMV}_{\mathrm{E}}\right)$. Source: Same as Figure 2.

\section{Conclusions}

An increase in corporate value - the assessment of the creation of value for owners in an expected and sufficient manner - was the basic topic of consideration in this article.

The critical measurement of a company's value creation based on MVA and EVA led to the extension of the area of their perception by introducing the concept of excess value (theoretical and methodological goals).

\section{References}

Alberts, W. W., \& McTaggart, J. M. (1984). Value based strategic investment planning. Interfaces, 14(1), $138-151$. http://dx.doi.org/10.1287/inte.14.1.138

Baker, M., Bradley, B., \& Wurgler, J. (2011). Benchmarks as Limits to Arbitrage: Understanding the Low-Volatility Anomaly. Financial Analyst Journal, 67 (1), 40-54, http://dx.doi.org/10.2469/faj.v67.n1.4

Benninga, S. Z., \& Sarig, O. H. (2003). Risk, returns, and values in the presence of differential taxation. Journal of Banking \& Finance, 27 (6), 1123-1138. http://dx.doi.org/ 10.1016/S0378-4266(02)00249-2
The paper presents a review of the selected results of the multiannual empirical research studies of a group of 104 companies. The presented results refer to 20 listed companies (including the sectors of energy, chemicals, fuel and raw materials), quoted on the Warsaw Stock Exchange. They represented the main creators and destroyers of value added in 2008-2013, constituting the main stock index (WIG-20).

The presented assessment of economic value added creation $\left(\mathrm{RI}_{\mathrm{E}} \sim \mathrm{EVA} \mathrm{A}_{\mathrm{E}}\right)$ is negative, while the measure of excess market value added turns out to be a significant source of information (MVA $\mathrm{EN}_{\text {). }}$.

The results of the conducted empirical studies lead to a number of conclusions related to mid-term assessments:

1. a positive verification of the hypothesis on the statistically significant and strong correlation between changes to excess market value added (MVA $\mathrm{EN}_{\mathrm{EN}}$ ) and changes to a company's market capitalisation $\left(\mathrm{MV}_{\mathrm{E}}\right)$,

2. the paper proves that excess market value added MVAEN $_{\text {EN }}$ provides a more reliable description (as compared with market value added) of capital market changes assessed on the basis of company's market capitalisation changes $\left(\mathrm{MV}_{\mathrm{E}}\right)$,

3. the paper shows that the measure of economic value added (internal assessment) is not consistent with external assessments based on the use of market value $\left(\mathrm{MV}_{\mathrm{E}}\right)$.

Supplementary conclusions based on the research study are as follows:

- the measure of market value $\left(\mathrm{MV}_{\mathrm{E}}\right)$ and market value added $\left(\mathrm{MVA} \mathrm{A}_{\mathrm{E}}\right)$ are long-term measures unlike the measure of economic value added (which refers to a specific period). On the other hand, market value added $\mathrm{MVA}_{\mathrm{E}}$ combines engaged capital and the sum of economic value added $\mathrm{RI}_{\mathrm{E}} \sim \mathrm{EVA} \mathrm{A}_{\mathrm{E}}$. Therefore, there should be a stronger correlation between $M V A_{E}$ and $\mathrm{RI}_{\mathrm{E}} \sim \mathrm{EVA} \mathrm{A}_{\mathrm{E}}$, even in mid-term periods,

- a positive value of MVA $\mathrm{EN}_{\mathrm{E}}$ can be accompanied by negative MVAER $_{E R}$ values due to lower negative MVAEP values, which results in an ambiguous situation. In this case, a real reduction in value added occurs despite a positive assessment from the point of view of $\mathrm{MVA}_{\mathrm{EN}}$ (J.A. Knigt regards such a situation as a premium) (Knight 1997). However, it would imply the discrimination of companies with positive $\mathrm{MVA}_{\mathrm{ER}}$ values. Therefore, it is justified to state that a positive assessment is conditioned by an increase in $\mathrm{MV}_{\mathrm{E}}$, which is at least equal to $\mathrm{MVA}_{\mathrm{EN}}$ (Malmi \& Ikaheimo 2003).

It should be expected that a wider scope of research and extended time series will allow for the verification of the hypothesis on the anticipatory character of signals from the external measures of created value (secondary ones - MV, MVA) in relation to signals from internal measures (primary ones $\left.-\mathrm{EVA}^{\mathrm{TM}}, \mathrm{DCF}\right)$. This issue is likely to be an area of further research. 
Bilgin, R., \& Basti E. (2014). Further Evidence on the Validity of CAPM: the Istanbul Stock Exchange Application. Inzinerine Ekonomika - Engineering Economics, 25(1), 5-7. http://dx.doi.org/10.5755/j01.ee.25.1.1847

Black, A., \& Wright, P. (2001). In search of shareholder value: managing the drivers of performance. London: Financial Times/Prentice Hall.

Bosse, P. M, Wimmer, B. R., \& Philips, Ch. B. (2013). Active bond-fund excess returns: Is it alpha...or beta? Vanguard research, September, 1-14. Available from internet: https://personal.vanguard.com/pdf/s809.pdf

Copeland, T., Dolgoff, A., \& Moel, A. (2004). The Role of Expectations in Explaining the Cross-Section of Stock Returns. Review of Accounting Studies, 9 (2-3), 149-188. https://doi.org/10.1023/B:RAST.0000028184.06279.57

Capron, L., \& Pistre, N. (2002). When do acquirers earn abnormal returns? Strategic Management Journal, 23(9), $781-794$. http://dx.doi.org/10.1002/smj.262

Cornell, B., \& Shapiro, A. C. (1987). Corporate Stakeholders and Corporate Finance. Financial Management, 16(1), 5-14. http://dx.doi.org/10.2307/3665543

Day, G., \& Fahey, L. (1988). Valuing Market Strategies. Journal of Marketing, 52(3), 45-57. http://dx.doi.org/ $10.2307 / 1251449$

Dean, J. (1954). Measuring the Productivity of Capital. Harvard Business Review, January-February.

Djuric, M., Milosevic, D., Filipovic, J., \& Ristic, S. (2013). Benchmarking as a Quality Management Tool in Public Administration. Inzinerine Ekonomika - Engineering Economics, 24(4), 364-367. http://dx.doi.org/10.5755/j01.e e.24.4.2785

Drucker, P. F. (1986). The Changed World Economy. Foreign Affairs, 64(4), 768-791. http://dx.doi.org/10.2307/20042687

Fernandez, P. (2001). A Definition of Shareholder Value Creation. Working Paper of University of Navarra - IESE Business School, 4, 3-4. http://dx.doi.org/10.2139/ssrn.268129

Gilmore, S., \& Hayashi, F. (2011). Emerging Market Currency Excess Returns. American Economic Journal Macroeconomics, 3 (4), 85-111, http://dx.doi.org/10.3386/w14528

Grinblatt, M., \& Titman, S. (1989). Mutual Fund Performance: An Analysis of Quarterly Portfolio Holdings. The Journal of Business, 62 (3), 393-416. http://dx.doi.org/10.1086/296468

Hartman, J. C. (2000). On the equivalence of net present value and market value added as measures of a project's economic worth. The Engineering Economist, 45(2), 158-165. http://dx.doi.org/10.1080/00137910008967543

Hillman, A. J., \& Keim G. D. (2001). Shareholder Value, Stakeholder Management, and Social Issues: What's the Bottom Line? Strategic Management Journal, 22 (2), 125-139. http://dx.doi.org/10.2307/3094310

Hubbard, R., \& Bayarri, M. J. (2012). Confusion Over Measures of Evidence (p's) Versus Errors ( $\alpha$ 's) in Classical Statistical Testing. The American Statistician, 57(3), 171-178. http://dx.doi.org/10.1198/0003130031856

Jensen, M. C., (1968). The Performance of Mutual Funds in the Period 1945-1964. Journal of Finance, 23, $389-416$. http://dx.doi.org/10.1111/j.1540-6261.1968.tb00815.x

Kaczmarek, J. (2014). Creating Shareholder Value in Listed Construction Companies. World of Real Estate Journal, 4(90), 71-76. Available from internet: http://yadda.icm.edu.pl/yadda/element/bwmeta1.element.ekon-element000171335459

Kaczmarek, J. (2014). The Quantification of Effectiveness in the Context of Shareholder Value and its Creation. In A. D'Amico, G. Moschella (Ed.), Enterprise in Hardship Economics, Managerial and Juridical Perspectives (pp. 293308). Roma: ARACNE editrice.

Knight, J. A. (1997). Value Based Management: Developing a Systematic Approach to Creating Shareholder Value. New York: McGraw-Hill.

Koller, T., Goedhart, M., \& Wessels D. (2010). Valuation: measuring and managing the value of companies. Hoboken (New Jersey): John Wiley and Sons. Available from internet: http://eu.wiley.com/WileyCDA/WileyTitle/productCd0470424702.html

Magni, C. A. (2003). Decomposition of net final values: Systemic Value Added and residual income. Bulletin of Economic Research, 55 (2), 149-176, http://dx.doi.org/10.1111/1467-8586.00167

Malmi, T., \& Ikaheimo, S. (2003). Value Based Management practices - some evidence from the field. Management Accounting Research, 14(3), 235-254. http://dx.doi.org/10.1016/S1044-5005(03)00047-7

Matuleviciene, M., \& Stravinskiene, J. (2015). The Importance of Stakeholders for Corporate Reputation. Inzinerine Ekonomika - Engineering Economics, 26(1), 75-77. http://dx.doi.org/10.5755/j01.ee.26.1.6921

Meng, X. L., Rosenthal, R., \& Rubin, D. B. (1992). Comparing correlated correlation coefficients. Psychological Bulletin, 111(1), 172-175. http://dx.doi.org/10.1037/0033-2909.111.1.172

McIntyre, E. V. (1999). Accounting choices and EVA. Business Horizons, 42(1), 66-72. http://dx.doi.org/10.1016/S00076813(99)80050-0

McTaggart, J. M., et al. (1995). The value imperative. Economic Record, 71(214), $305-306$. http://dx.doi.org/10.1111/j.1475-4932.1995.tb01896.x 
Mikolajek-Gocejna, M. (2010). Rynkowe miary tworzenia wartosci przedsiębiorstwa i wartosci dla akcjonariuszy. Efinanse, 6, 49-50. Available from internet: http://www.e-finanse.com/artykuly/166.pdf?origin=publication_detail

Miller, M. H., \& Scholes, M. S. (1978). Dividends and taxes. Journal of Financial Economics, 6(4), 333-364. http://dx.doi.org/10.1016/0304-405X(78)90009-0

Modigliani, F., \& Miller, M. H. (1958). The Cost of Capital, Corporation Finance and the Theory of Investment. The American Economic Review, 48(3), 261-297. Available from internet: http://www.jstor.org/stable/1809766

Myers, S. C. (1984). The Capital Structure Puzzle. The Journal of Finance, 39, 574-592. http://dx.doi.org/10.1111/j.15406261.1984.tb03646.x

Nurwati, A., \& Ramdi, Z. (2013). The Effect of Market Excess Returns, Size, Market-to-Book Ratio and Earnings Yield on Stock Returns. International Business Management, 7 (4), 267-277. http://dx.doi.org/10.3923/ibm.2013.267.277

Nyiramahoro, B., \& Shooshina, N. (2001). Creating and Measuring Shareholder Value, Applicability and Relevance in Selected Swedish Companies. International Accounting and Finance Master Thesis, 8, 43-57. Available from internet: http://citeseerx.ist.psu.edu/viewdoc/summary?doi=10.1.1.198.2950\&rank=1

O'Hanlon, J., \& Peasnell, K. (2002). Residual Income and Value Creation: The Missing Link. Review of Accounting Studies. 7 (2), 229-245. http://dx.doi.org/10.1023/A:1020230203952

O'Hanlon, J. F., \& Peasnell, K. V. (2000). Residual income and EVA. Economic and Financial Computing, 10, 53-95. Available from internet: http://eprints.lancs.ac.uk/43397/

Ohlson. J.A. (1995). Earnings, book values, and dividends in equity valuation. Contemporary Accounting Research, 11 (2), 661-687, http://dx.doi.org/10.1111/j.1911-3846.1995.tb00461.x

Parker, R. H. (1968). Discounted Cash Flow in Historical Perspective. Journal of Accounting Research, 6(1), 58-71. http://dx.doi.org/10.2307/2490123

Peasnell, K. V. (1982). Some formal connections between economic values and yields and accounting numbers. Journal of Business Finance \& Accounting, 9(3), 361-381. http://dx.doi.org/10.1111/j.1468-5957.1982.tb01001.x

Perotti, P., \& Wagenhofer, A. (2011). Earnings quality measures and excess returns. Journal of Business Finance \& Accounting, 41 (5) \& (6), 545-571. http://dx.doi.org/10.1111/jbfa.12071

Pfeiffer, T. (2004). Net Present Value - Consistent Investment Criteria Based on Accruals: A Generalisation of the Residual Income-Identity. Journal of Business Finance \& Accounting, 31(7-8), 905-926. http://dx.doi.org/10.1111/j.0306686X.2004.00561.x

Rappaport, A. (1999). Creating Shareholder Value. A Guide for Managers and Investors. New York: The Free Press/Simon and Schuster.

Rappaport, A. (2006). Ten Ways to Create Shareholder Value. Harvard Business Review. 84(9), 66-77. Available from internet: https://hbr.org/2006/09/ten-ways-to-create-shareholder-value

Solomons, D. (1965). Divisional Performance: Measurement and Control. Homewood. Illinois: Richard D. Irwin Publishing.

Srivastava, R. K, Shervani, T. A., \& Fahey, L. (1998). Market-Based Assets and Shareholder Value: A Framework for Analysis. Journal of Marketing, 62(1) 2-18. http://dx.doi.org/10.2307/1251799

Steiger, J. H. (1980). Tests for comparing elements of a correlation matrix. Psychological Bulletin, 87(2), 245-251. http://dx.doi.org/10.1037/0033-2909.87.2.245

Stern, J. M, Stewart, G. B., \& Chew, D. H. Jr. (1996). Eva®: An integrated financial management system. European Financial Management, 2(2), 223-245. http://dx.doi.org/10.1111/j.1468-036X.1996.tb00039.x

Wasserstein, R. L., \& Lazar, N. A. (2016). The ASA's Statement on p-Values: Context, Process, and Purpose. The American Statistician, 70(2), 129-133. https://doi.org/10.1080/00031305.2016.1154108

The article has been reviewed.

Received in September, 2015; accepted in September, 2018. 